\title{
Genotyping of Erwinia carotovora subsp. carotovora Strains from Asia Based on recA Gene Restriction Fragment Length Polymorphisms
}

\section{Seo, Sang-Tae}

Laboratory of Plant Pathology, Division of Plant Pathology and Pesticide Science, Department of Applied Genetics and Pest Management, Graduate School of Bioresource and Bioenvironmental Sciences, Kyushu University

\section{Furuya, Naruto}

Laboratory of Plant Pathology, Division of Plant Pathology and Pesticide Science, Department of Applied Genetics and Pest Management, Faculty of Agriculture, Kyushu University

Takeshita, Minoru

Laboratory of Plant Pathology, Division of Plant Pathology and Pesticide Science, Department of Applied Genetics and Pest Management, Faculty of Agriculture, Kyushu University

Takanami, Yoichi

Laboratory of Plant Pathology, Division of Plant Pathology and Pesticide Science, Department of Applied Genetics and Pest Management, Faculty of Agriculture, Kyushu University

https://doi.org/10.5109/24453

出版情報: 九州大学大学院農学研究院紀要. 47 (1)，pp.7-12，2002-10-30. Kyushu University バージョン：

権利関係: 


\title{
Genotyping of Erwinia carotovora subsp. carotovora Strains from Asia Based on recA Gene Restriction Fragment Length Polymorphisms
}

\author{
Sang-Tae SEO*, Naruto FURUYA, Minoru TAKESHITA \\ and Yoichi TAKANAMI \\ Laboratory of Plant Pathology, Division of Plant Pathology and Pesticide Science, \\ Department of Applied Genetics and Pest Management, Faculty of Agriculture, \\ Kyushu University, Fukuoka 812-8581, Japan \\ (Received June 24, 2002 and accepted July 12, 2002)
}

\begin{abstract}
Genetic diversity of a collection of 92 strains of Erwinia carotovora subsp. carotovora (Ecc) isolated from various host plants in Asian countries (Japan, Korea and Thailand) was assessed by means of PCR-RFLP of recombinase A gene (recA). Ten RFLP groups were obtained on the basis of restriction analysis of recA gene fragments with four restriction endonucleases (Hind II, Alu I, Dde I and Tas I). Most of Asian strains (71 out of 92 strains) belonged to RFLP groups 1, 2 and 3. When the RFLP groups were compared with the phenotypic groups and hosts of origin, there were found some relationships. RFLP groups 2 and 3 coincided with phenotypic groups $A$ and $B$, respectively. RFLP group 4 contained only isolates from mulberry trees, indicating that the mulberry strains are in a distinct group in Ecc. The results of this study will facilitate further understanding of the population structure of Ecc in Asia.
\end{abstract}

\section{INTRODUCTION}

Erwinia carotovora subsp. carotovora (Ecc) is a member of the pathogenic enterobacteria causing soft rot of a wide range of plants in different parts of the world (Perombelon and Kelman, 1980). Ecc is a complex unit in which strains are diverse at various levels. The diversity within the population may result from several factors such as genetic change, host plants, migration from other geographic areas, etc.

Analysis of genetic diversity is important for understanding the distribution of the strains. Several studies of taxonomy and diversity of Ecc strains have previously been undertaken using molecular techniques, such as PCR-RFLP (Darrasse et al., 1994), AFLP (Avrova et al., 2002), RAPD (Hadas et al., 2001; Maki-Valkama and Karjalainen, 1994) and 16S rDNA analyses (Hauben et al., 1998). They have confirmed the heterogeneity of the Ecc by the various techniques. However, most of the studies concerning genetic diversity of the pathogen have not included Asian strains, and little is known about genetic diversity of Ecc strains in Asian areas.

Recombinase A (RecA) is a multifunctional protein involved in homologous recombination, DNA repair and the SOS response (Eisen, 1995). Waleron et al. (2002) reported

\footnotetext{
* Laboratory of Plant Pathology, Division of Plant Pathology and Pesticide Science, Department of Applied Genetics and Pest Management, Graduate School of Bioresource and Bioenvironmental Sciences, Kyushu University
} 
the usefulness of the recA PCR-RFLP for genotyping of Ecc, but Asian strains were not included in their work. Therefore, we have also tried to assess the diversity of Ecc strains obtained from Asian areas by means of PCR-RFLP of the recA gene, and have compared the results of the genotyping with previously determined phenotypic groups (Seo et al., 2002), hosts and geographic origins.

\section{MATERIALS AND METHODS}

\section{Bacterial strains}

The bacterial strains used in this study are listed in Table 1. All the strains were routinely cultured on MGY agar (mannitol $10.0 \mathrm{~g}$, L-glutamic acid $2.0 \mathrm{~g}, \mathrm{KH}_{2} \mathrm{PO}_{4} 0.5 \mathrm{~g}, \mathrm{NaCl}$ $0.2 \mathrm{~g}, \mathrm{MgSO}_{4} \cdot 7 \mathrm{H}_{2} \mathrm{O} 0.2 \mathrm{~g}$, yeast extract $0.25 \mathrm{~g}$, agar $15.0 \mathrm{~g}$, distilled water 1 liter, $\mathrm{pH} 7.0$ ) at $28^{\circ} \mathrm{C}$ for 2 days (Keane et al., 1970).

\section{PCR-RFLP of the $\operatorname{rec} A$ gene}

For performing PCR, total DNA was extracted according to the method of Sambrook et al. (1989). PCR was performed in a thermal cycler (Astec, Japan) by using the primers previously described (Waleron et al., 2002). Amplification was performed in a reaction mixture of total volume of $50 \mu l$ containing $67 \mathrm{mM}$ Tris/ $\mathrm{HCl}(\mathrm{pH} 8.8), 2.0 \mathrm{mM} \mathrm{MgCl}$, $0.125 \mathrm{mM}$ each of dATP, dCTP, dGTP and dTTP, 2.0 units of Taq DNA polymerase (TOYOBO, Japan), $50 \mathrm{pmol}$ each primer, and $1 \mu \mathrm{l}$ of a $50 \mathrm{ng} / \mathrm{ml}$ solution of purified DNA. The mixture was overlaid with $50 \mu \mathrm{l}$ of mineral oil. PCR reactions were performed under the following conditions; $95^{\circ} \mathrm{C}$ for $3 \mathrm{~min}$ for the first cycle, 35 cycles of $94^{\circ} \mathrm{C}$ for $1 \mathrm{~min}$, $51{ }^{\circ} \mathrm{C}$ for $1 \mathrm{~min}$ and $72^{\circ} \mathrm{C}$ for $2 \mathrm{~min}$, and a final cycle of $72^{\circ} \mathrm{C}$ for $5 \mathrm{~min}$. The amplified DNA fragments were digested with the following restriction endonucleases (Fermentas, Lithuania): Hind III, Dde I, Alu I and Tas I, according to the manufacturer's instructions. The reaction products were analyzed by agarose $(2 \%, \mathrm{w} / \mathrm{v})$ gel electrophoresis in $1 \times \mathrm{TBE}$ buffer and visualized by staining with ethidium bromide.

\section{RESULTS AND DISCUSSION}

All products obtained after PCR amplification with the primers designed to be complementary to the $E$. carotovora recA gene were of the expected size (about 730 base pairs in length). The PCR products were digested with four restriction enzymes (Hind II, Dde I, Alu I and Tas I) for RFLP analysis. Each of Hind II and Alu I gave its own one restriction pattern, while each of Dde I and Tas I gave four RFLP patterns. The obtained PCR-RFLP patterns showed that there are ten RFLP groups. Representative RFLP patterns and the groups associated with the respective strains are given in Figure 1 and Table 1, respectively. Most of the strains (71 out of 92 strains) tested belong to RFLP group 1, 2 and 3. Waleron et al. (2002) reported that 57 Ecc strains isolated from 13 host plants in mainly European countries were divided into 18 different RFLP groups by analysis of the recA gene. Thus, Asian strains isolated from 35 host plants are more homogeneous than the European strains.

We previously reported that Asian Ecc strains were composed of two groups, A (typical Ecc) and B (atypical Ecc), on the basis of 26 phenotypic characteristics (Seo et 
Table 1. Origin, phenotypic groups, PCR-RFLP patterns and RFLP groups of E. carotovora subsp. carotovora strains used in this experiment

\begin{tabular}{|c|c|c|c|c|c|c|c|c|}
\hline \multirow[b]{2}{*}{ Strain } & \multirow[b]{2}{*}{ Host } & \multirow{2}{*}{$\begin{array}{c}\text { Geographic } \\
\text { origin and year } \\
\text { isolated }\end{array}$} & \multirow{2}{*}{$\begin{array}{l}\text { Pheno- } \\
\text { typic } \\
\text { group }^{b}\end{array}$} & \multicolumn{4}{|c|}{ PCR-RFLP patterns ${ }^{c}$} & \multirow{2}{*}{$\begin{array}{l}\text { RFLP } \\
\text { group }\end{array}$} \\
\hline & & & & Hind III & Dde I & Alu I & Tas I & \\
\hline N7101 & Sweet pepper & Japan, 1971 & $\mathrm{~B}$ & 1 & 1 & 1 & 1 & 1 \\
\hline N7109 & Cauliflower & Japan, 1971 & $B$ & 1 & 1 & 1 & 1 & 1 \\
\hline N7116 & Cabbage & Japan, 1971 & $\mathrm{~B}$ & $\hat{1}$ & 1 & 1 & 1 & 1 \\
\hline N7129 & Radish & Japan, 1971 & A & 1 & 1 & 1 & 1 & 1 \\
\hline N7135 & Tomato & Japan, 1971 & $B$ & 1 & 1 & 1 & 1 & 1 \\
\hline Sr79-33-3 & Potato & Japan, 1979 & A & 1 & 1 & 1 & 1 & 1 \\
\hline $1 \mathrm{~B}$ & Shallot & Japan, 1982 & A & 1 & 1 & 1 & 1 & 1 \\
\hline $645 \mathrm{ar}$ & Chinese cabbage & Japan, 1960 & A & 1 & 1 & 1 & 1 & 1 \\
\hline $\mathrm{K} 1$ & Radish & Japan, 1985 & A & 1 & 1 & 1 & $\hat{1}$ & 1 \\
\hline $\mathrm{K} 2$ & Radish & Japan, 1985 & A & 1 & 1 & 1 & 1 & 1 \\
\hline MAFF 106567 & Cucumber & Japan, 1985 & $\mathrm{~A}$ & 1 & 1 & 1 & 1 & 1 \\
\hline MAFF 301049 & Eggplant & Japan, 1948 & A & 1 & 1 & 1 & 1 & 1 \\
\hline MAFF 301282 & Melon & Japan, 1976 & $\mathrm{~A}$ & 1 & $\hat{1}$ & 1 & 1 & 1 \\
\hline MAFF 301394 & Cabbage & Japan, 1971 & $B$ & 1 & 1 & 1 & 1 & 1 \\
\hline MAFF 301404 & Parsley & Japan, 1973 & $\mathrm{~A}$ & 1 & 1 & 1 & 1 & 1 \\
\hline MAFF 301917 & Cauliflower & Japan, 1971 & A & 1 & 1 & 1 & 1 & 1 \\
\hline MAFF 311115 & Calla & Japan, 1994 & $\mathrm{~A}$ & 1 & 1 & 1 & 1 & 1 \\
\hline MAFF 810035 & Lettuce & Japan, 1980 & A & 1 & 1 & 1 & 1 & 1 \\
\hline MAFF 810020 & Mulberry & Japan, 1980 & - & 1 & 1 & 1 & 1 & 1 \\
\hline MAFF 810030 & Mulberry & Japan, 1980 & - & 1 & 1 & 1 & 1 & 1 \\
\hline Ecc3/95 & Potato & Korea, 1995 & $B$ & 1 & 1 & 1 & 1 & 1 \\
\hline Ecc1/96 & Chinese cabbage & Korea, 1996 & $\mathrm{~A}$ & 1 & 1 & 1 & 1 & 1 \\
\hline Ecc3/96 & Chinese cabbage & Korea, 1996 & $\mathrm{~A}$ & 1 & 1 & 1 & 1 & 1 \\
\hline Ecc $4 / 96$ & Chinese cabbage & Korea, 1996 & A & 1 & 1 & 1 & 1 & 1 \\
\hline Ecc6/96 & Wasabi & Korea, 1996 & $\mathrm{~A}$ & 1 & 1 & 1 & 1 & 1 \\
\hline Ecc $8 / 96$ & Crisphead & Korea, 1996 & $\mathrm{~A}$ & 1 & 1 & 1 & 1 & 1 \\
\hline Ecc $9 / 96$ & Radish & Korea, 1996 & $\mathrm{~A}$ & 1 & 1 & 1 & 1 & 1 \\
\hline Ecc13/96 & Pumpkin & Korea, 1996 & A & 1 & 1 & 1 & 1 & 1 \\
\hline Ecc3/97 & Potato & Korea, 1997 & A & 1 & 1 & 1 & 1 & 1 \\
\hline Eccl/98 & Cactus & Korea, 1998 & $\mathrm{~A}$ & 1 & 1 & 1 & 1 & 1 \\
\hline $014-2$ & Cauliflower & Thailand, 1980 & A & 1 & 3 & 1 & 1 & 2 \\
\hline $014-9$ & Cauliflower & Thailand, 1980 & A & 1 & 3 & 1 & 1 & 2 \\
\hline $435-2$ & Lettuce & Thailand, 1982 & A & 1 & 3 & 1 & 1 & 2 \\
\hline $435-6$ & Lettuce & Thailand, 1982 & $\mathrm{~A}$ & 1 & 3 & 1 & 1 & 2 \\
\hline $485-5$ & Cabbage & Thailand, 1982 & A & 1 & 3 & 1 & 1 & 2 \\
\hline $489-4$ & Cabbage & Thailand, 1982 & $\mathrm{~A}$ & 1 & 3 & 1 & 1 & 2 \\
\hline $489-5$ & Cabbage & Thailand, 1982 & $\mathrm{~A}$ & 1 & 3 & 1 & 1 & 2 \\
\hline $493-1$ & Potato & Thailand, 1982 & $\mathrm{~A}$ & 1 & 3 & 1 & 1 & 2 \\
\hline $493-3$ & Potato & Thailand, 1982 & $\mathrm{~A}$ & 1 & 3 & 1 & 1 & 2 \\
\hline $493-5$ & Potato & Thailand, 1982 & $\mathrm{~A}$ & 1 & 3 & 1 & 1 & 2 \\
\hline Ku7514 & Watermelon & Japan, 1975 & $\mathrm{~B}$ & 1 & 3 & 1 & 1 & 2 \\
\hline EH8504 & Cucumber & Japan, 1985 & $\mathrm{~A}$ & 1 & 3 & 1 & 1 & 2 \\
\hline $\mathrm{EH} 8510$ & Cucumber & Japan, 1985 & A & 1 & 3 & 1 & 1 & 2 \\
\hline EH8514 & Cucumber & Japan, 1985 & $\mathrm{~A}$ & 1 & 3 & 1 & 1 & 2 \\
\hline EH8519 & Cucumber & Japan, 1985 & $\mathrm{~A}$ & 1 & 3 & 1 & 1 & 2 \\
\hline MAFF 301891 & Sweet pepper & Japan, 1971 & A & 1 & 3 & 1 & 1 & 2 \\
\hline Eccl/95 & Wasabi & Korea, 1995 & $\mathrm{~A}$ & 1 & 3 & 1 & 1 & 2 \\
\hline Ecc $4 / 95$ & Chinese cabbage & Korea, 1995 & $\mathrm{~A}$ & 1 & 3 & 1 & 1 & 2 \\
\hline Ecc5/95 & Chinese cabbage & Korea, 1995 & $\mathrm{~A}$ & 1 & 3 & 1 & 1 & 2 \\
\hline Ecc6/95 & Potato & Korea, 1995 & $\mathrm{~A}$ & 1 & 3 & 1 & 1 & 2 \\
\hline $\operatorname{Eccl} / 97$ & Pepper & Korea, 1997 & A & 1 & 3 & 1 & 1 & 2 \\
\hline N7 127 & Carrot & Japan, 1971 & B & 0 & 1 & 0 & 1 & 3 \\
\hline N7128 & Celery & Japan, 1971 & $B$ & 0 & 1 & 0 & 1 & 3 \\
\hline
\end{tabular}


Table 1. Continued

\begin{tabular}{|c|c|c|c|c|c|c|c|c|}
\hline \multirow[b]{2}{*}{ Strain ${ }^{2}$} & \multirow[b]{2}{*}{ Host } & \multirow{2}{*}{$\begin{array}{l}\text { Geographic } \\
\text { origin and year } \\
\text { isolated }\end{array}$} & \multirow{2}{*}{$\begin{array}{l}\text { Pheno- } \\
\text { typic } \\
\text { group }^{\text {h) }}\end{array}$} & \multicolumn{4}{|c|}{ PCR-RFLP patterns") } & \multirow{2}{*}{$\begin{array}{l}\text { RFLP } \\
\text { group }^{\text {d) }}\end{array}$} \\
\hline & & & & Hind III & Dde I & Alu I & Tas I & \\
\hline N7131 & Tomato & Japan, 1971 & B & 0 & 1 & 0 & 1 & 3 \\
\hline N7157 & Chinese cabbage & Japan, 1971 & $\mathrm{~B}$ & 0 & 1 & 0 & 1 & 3 \\
\hline S8488 & Sunflower & Japan, 1984 & B & 0 & 1 & 0 & 1 & 3 \\
\hline 190 & Carrot & Japan, 1984 & $B$ & 0 & 1 & 0 & 1 & 3 \\
\hline 43 & Cabbage & Japan, 1984 & B & 0 & 1 & 0 & 1 & 3 \\
\hline $\operatorname{ar} 13$ & Chinese cabbage & Japan, 1960 & $\mathrm{~B}$ & 0 & 1 & 0 & 1 & 3 \\
\hline 20 & Chinese cabbage & Japan, 1970 & $\mathrm{~B}$ & 0 & 1 & 0 & 1 & 3 \\
\hline MAFF 301053 & Radish & Japan, 1957 & B & 0 & 1 & 0 & 1 & 3 \\
\hline MAFF 301396 & Carrot & Japan, 1971 & $\mathrm{~B}$ & 0 & 1 & 0 & 1 & 3 \\
\hline MAFF 301399 & Elephant's foot & Japan, 1971 & $B$ & 0 & 1 & 0 & 1 & 3 \\
\hline MAFF 301905 & Tobacco & Japan, 1971 & B & 0 & 1 & 0 & 1 & 3 \\
\hline MAFF 302773 & Garlic & Japan, 1983 & $B$ & 0 & 1 & 0 & 1 & 3 \\
\hline MAFF 810032 & Mulberry & Japan, 1980 & - & 0 & 1 & 0 & 1 & 3 \\
\hline Ecc2/95 & Chicory & Korea, 1995 & B & 0 & 1 & 0 & 1 & 3 \\
\hline Ecc5/96 & Chinese cabbage & Korea, 1996 & B & 0 & 1 & 0 & 1 & 3 \\
\hline Ecc7/96 & Onion & Korea, 1996 & $B$ & 0 & 1 & 0 & 1 & 3 \\
\hline Ecc11/96 & Potato & Korea, 1996 & $B$ & 0 & 1 & 0 & 1 & 3 \\
\hline Ecc12/96 & Cucumber & Korea, 1996 & $\mathrm{~B}$ & 0 & 1 & 0 & 1 & 3 \\
\hline MAFF 301937 & Mulberry & Japan, 1974 & $\mathrm{~B}$ & 1 & 4 & 1 & 1 & 4 \\
\hline MAFF 810017 & Mulberry & Japan, 1969 & - & 1 & 4 & 1 & 1 & 4 \\
\hline MAFF 810022 & Mulberry & Japan, 1979 & - & 1 & 4 & 1 & 1 & 4 \\
\hline MAFF 810029 & Mulberry & Japan, 1980 & - & 1 & 4 & 1 & 1 & 4 \\
\hline MAFF 810031 & Mulberry & Japan, 1980 & - & 1 & 4 & 1 & 1 & 4 \\
\hline MAFF 810034 & Mulberry & Japan, 1982 & - & 1 & 4 & 1 & 1 & 4 \\
\hline $168-7$ & Chinese cabbage & Thailand, 1980 & A & 1 & 2 & 1 & 3 & 5 \\
\hline $486-4$ & Sweet pepper & Thailand, 1982 & A & 1 & 2 & 1 & 3 & 5 \\
\hline $486-5$ & Sweet pepper & Thailand, 1982 & A & 1 & 2 & 1 & 3 & 5 \\
\hline $486-7$ & Sweet pepper & Thailand, 1982 & A & 1 & 2 & 1 & 3 & 5 \\
\hline $486-8$ & Sweet pepper & Thailand, 1982 & $\mathrm{~A}$ & 1 & 2 & 1 & 3 & 5 \\
\hline $476-4$ & Bird chili & Thailand, 1982 & A & 1 & 2 & 1 & 1 & 6 \\
\hline $476-7$ & Bird chili & Thailand, 1982 & $\mathrm{~A}$ & 1 & 2 & 1 & 1 & 6 \\
\hline MAFF 301941 & Ginger & Japan, 1974 & $\mathrm{~A}$ & 1 & 2 & 1 & 1 & 6 \\
\hline $131-1$ & Bell pepper & Thailand, 1980 & $A$ & 1 & 2 & 1 & 2 & 7 \\
\hline $479-2$ & Coriander & Thailand, 1982 & $\mathrm{~A}$ & 1 & 2 & 1 & 2 & 7 \\
\hline Ecc $2 / 97$ & Calla & Korea, 1997 & A & 1 & 2 & 1 & 2 & 7 \\
\hline $473-1$ & Chinese cabbage & Thailand, 1982 & A & 0 & 2 & 0 & 1 & 8 \\
\hline $475-1$ & Hot pepper & Thailand, 1982 & A & 0 & 2 & 0 & 1 & 8 \\
\hline Ecc2/96 & Chinese cabbage & Korea, 1996 & B & 0 & 1 & 0 & 4 & 9 \\
\hline B1 & Broccoli & Japan, 1985 & $\mathrm{~A}$ & 1 & 1 & 1 & 2 & 10 \\
\hline
\end{tabular}

a) MAFF, Ministry of Agriculture, Forestry and Fisheries Gene Bank, Japan

b) As described by Seo et al. (2002); -, not determined

c) Numbers correspond to RFLP patterns shown in Fig. 1. Zero indicates the absence of restriction digestion by a given endonuclease

t) Numbers of RFLP groups based on the combined PCR-RFLP patterns

$a l ., 2002)$. When the recA RFLP groups were compared with the two phenotypic groups, RFLP groups 2 and 3 were composed of phenotypic groups A and B, respectively, except one strain (Ku7514) (Table 1). These results showed a close relationship between genetic groups by the recA RFLP analysis and phenotypic ones. However, no association 

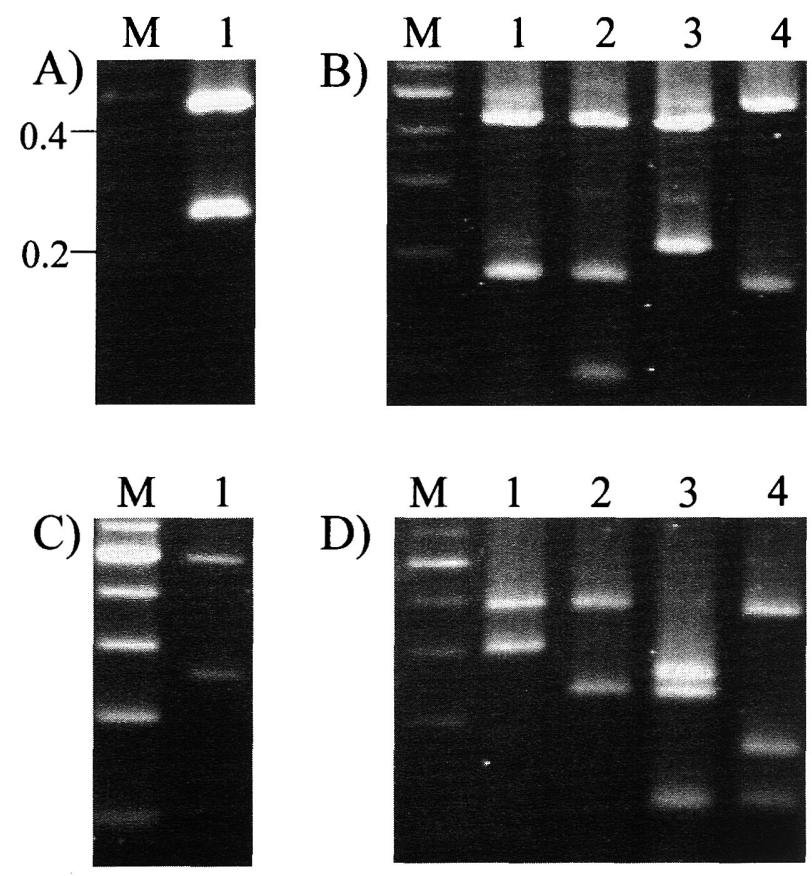

Fig. 1. RFLP analysis of the amplified fragments of recA gene. The DNA products of recA gene were digested with restriction enzyme Hind III (A), Dde I (B), Alu I (C) and Tas I (D), and separated on $2 \%$ agarose gels, stained with ethidium bromide, and photographed under UV illumination. Lane M, Molecular marker (kb). Lane numbers correspond to the PCR-RFLP patterns obtained for each restriction enzyme as shown in Table 1 .

was found between the genetic groups and geographic origins of the strains.

RFLP profiles of the recA gene of the strains were not strictly correlated to their hosts of origin. This result agrees with those by Waleron et al. (2002). RFLP group 4 consists of only six isolates from mulberry trees. Among the four endonucleases used in RFLP analysis, Dde I could differentiate the six mulberry strains from other Ecc strains.

To understand evolution and differentiation of the pathogen, further research is necessary. Combined with information already published for other parts of the world on the population structure of Ecc, a more comprehensive understanding of this pathogen is emerging.

\section{REFERENCES}

Avrova, A. O., L. J. Hyman, R. L. Toth and I. K. Toth 2002 Application of amplified fragment length polymorphism fingerprinting for taxonomy and identification of the soft rot bacteria Erwinia 
carotovora and Erwinia chrysanthemi. Appl. Environ. Microbiol., 68: 1499-1508

Darrasse, A., S. Priou, A. Kotoujansky and Y. Bertheau 1994 PCR and restriction fragment length polymorphism of a pel gene as a tool to identify Erwinia carotovora in relation to potato diseases. Appl. Environ. Microbiol., 60: 1437-1443

Eisen, J. A. 1995 The RecA protein as a model molecule for molecular systematic studies of bacteria: comparison of trees of RecAs and 16S rRNAs from the same species. J. Mol. Evol., 41: 1105-1123

Hadas, R., G. Kritzman, T. Gefen and S. Manulis 2001 Detection, quantification and characterization of Erwinia carotovora ssp. carotovora contaminating pepper seeds. Plant Pathol., 50: 117--123

Hauben, L., E. R. Moore, L. Vauterin, M. Steenackers, J. Mergaert, L. Verdonck and J. Swings 1998 Phylogenetic position of phytopathogens within the Enterobacteriaceae. Syst. Appl. Microbiol., 21: 384-397

Keane, P. J., A. Kerr and P. B. New 1970 Crown gall of stone fruit. II. Identification and nomenclature of Agrobacterium isolates. Aust. J. Biol. Sci., 23: 585-595

Maki-Valkama, T. and R. Karjalainen 1994 Differentiation of Erwinia carotovora subsp. atroseptica and carotovora by RAPD-PCR. Ann. Appl. Biol., 125: 301-309

Perombelon, M. C. M. and A. Kelman 1980 Ecology of the soft rot erwinias. Ann. Rev. Phytopathol., 18: 361-387

Sambrook, J., E. F. Fritsch and T. Maniatis 1989 Molecular cloning: a laboratory manual, $2^{\text {nd }}$ edn. Cold Spring Harbor, N. Y. (U.S.A.)

Seo, S. T., N. Furuya, C. K. Lim, N. Takanami and K. Tsuchiya 2002 Phenotypic and genetic diversity of Erwinia carotovora ssp. carotovora strains from Asia. J. Phytopathol., 150: 120-127

Waleron, M., K. Waleron, A. J. Podhajska and E. Lojkowska 2002 Genotyping of bacteria belonging to the former Erwinia genus by PCR-RFLP analysis of a recA gene fragment. Microbiology, 148: 583-595 